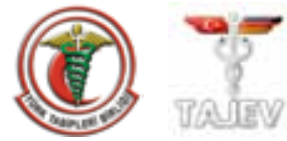

\title{
A close look at the contraction and relaxation of the myometrium; the role of calcium
}

\author{
Myometriyumun kasılma ve gevşeme mekanizmalarında kalsiyumun rolü
}

\author{
Bilge Pehlivanoğlu, Sibel Bayrak, Murat Doğan \\ Department of Physiology, Hacettepe University Faculty of Medicine, Ankara, Turkey
}

\section{Abstract}

The function and regulation of the myometrium, especially during pregnancy, labour and birth are important in reproductive physiology. It is crucial to understand the mechanisms that generate and modulate uterine contractility in order to be able to prevent and/or treat the problems related with the myometrium. A limited understanding of the cellular and molecular events underlying these phenomena complicates the situation. Various agonists, hormones, transmitters and/or chemicals are related to the regulation of the functions of the myometrium. Although notable advances regarding the key steps in receptor signalling explaining the actions of these factors have been achieved, a good deal of information is still necessary to understand this vital process. A better comprehension of myometrium physiology and the translation of research findings to clinical settings will help progress in women's health. In this review, we attempt to present a critical overview of myometrial functions and focus specifically on the role of calcium. (J Turkish-German Gynecol Assoc 2013; 14: 230-4)

Key words: Myocytes, contraction, relaxation, calcium, sensitisation Received: 20 June, 2013

Accepted: 12 August, 2013
Özet

Üreme fizyolojisi açısından myometriyumun işlevleri ve bu işlevlerin özellikle gebelik süreci ve doğum sırasında düzenlenmeleri çok önemlidir. Uterus kasılmalarını başlatan ve etkileyen faktörlerin anlaşlabilmesi myometriyumu ilgilendiren patolojik durumların engellenmesi ve/veya tedavi edilebilmesi için çok önemlidir. Ancak bu fizyolojik düzenlemeyi kontrol eden hücresel ve moleküler olayların tam olarak açıklanamamış olması nedeni ile tablo hala karmaşıktır. Çok sayıda agonistin, hormonların, transmiterlerin ve kimyasal maddelerin myometriyum işlevlerinin düzenlenmesinde rolü olduğu gösterilmiş ve bunların etki mekanizmalarındaki bazı anahtar basamaklar ile ilgili gelişmeler kaydedilmiş olmasına karşın, bu yaşamsal işlevi daha iyi açılayabilmek için daha fazla bilgiye ihtiyaç vardır. Myometriyumun fizyolojik özelliklerinin anlaşılması, araştırma sonuçlarının klinik uygulamalara yansıtılması kadın sağlığı açısından önemli katkı sağlayacaktır. Bu derlemede myometriyumun işlevlerini ve özellikle kalsiyumun rolünü özetlemeyi amaçladık.

(J Turkish-German Gynecol Assoc 2013; 14: 230-4)

Anahtar kelimeler: Miyositler, kasılma, gevşeme, kalsiyum, sensitizasyon

Geliş Tarihi: 20 Haziran 2013

Kabul Tarihi: 12 Ağustos 2013

\section{Introduction}

The uterus, more specifically the smooth muscle layer of the uterus, the myometrium, is an often overlooked tissue. Even though the myometrium is active throughout a woman's life, not just during labour and delivery, it is rarely considered until things go wrong which may have devastating consequences. However, the uterine myometrium serves life-long by contracting at the right time with exactly the desired amount of force during labour and the postpartum period and remaining relaxed even though distended enormously during the period of pregnancy, as well as maintaining its tonus in nonpregnant, non-menstruating periods. Some of the unwanted but frequently seen results of myometrial dysfunction are untimed contractions leading to abortions or preterm delivery, or stronger than necessary contractions causing foetal distress, hypoxia and even death of the foetus. In addition, dysfunctional labour can be faced and caesarean section may become inevitable when the force of the contractions are not strong enough and/or contractions are irregular $(1,2)$. Since the mechanisms that generate and modulate uterine contractility are not fully known, the aberrant patterns of contractile activity remain unsolved (3). Due to these limited answers, the therapeutic or preventive approaches to clinical conditions are not as successful as desired. In this review, we aimed to summarise the current knowledge about the mechanisms of contraction and relaxation of the myometrium and specifically the role of calcium $\left(\mathrm{Ca}^{+2}\right)$.

\section{Contraction of the Myometrium}

Uterine contractility, which occurs throughout the menstrual cycle in non-pregnant and pregnant states, is a complex and dynamic physiological phenomenon (2). Non-pregnant myometrium exhibits different contractions at different phases of the menstrual cycle; the first one is rhythmic, 'wave-like' contractions, which is sometimes known as uterine peristalsis, while the second type of contraction is defined as the 'focal and sporadic bulging of the myome- 
trium' $(4,5)$, leading to sustained contractions. These contractions serve in the sloughing of the endometrium (6) and help the passage of sperm. The myometrium in the pregnant uterus transforms from a silent, non-contracting state to an actively and forcefully contracting organ for a successful delivery. This is achieved by morphological changes and adaptations under the effect of elevated oestrogen and progesterone and the balance between these two hormones; these interactions are reviewed elsewhere as they are beyond the purpose of this review $(7,8)$. Besides the above-mentioned functional differences, regardless of the presence or absence of pregnancy, uterine contractions are dependent on the contractile activity of the cellular elements, the uterine myocytes. The uterine myocytes are smooth muscle cells exhibiting a phasic contractile pattern which can be summarised as the maintenance of a resting tone superimposed by separate intermittent contractions of varying frequency, amplitude and duration. It is predominantly regulated by intracellular calcium concentration $\left(\left[\mathrm{Ca}^{+2}\right] \mathrm{i}\right)(1,2,8)$.

\section{Cellular Organisation}

The contractile machinery of the uterine smooth muscles involves actin and myosin myofilaments with six times preponderance of actin to myosin. The thin myofilaments composed of polymers of globular actin monomers and thick filaments are made up of myosin helices lying parallel to the longitudinal axis of the cell. In addition, there are intermediate filaments composed of predominantly desmin and vimentin.

\section{Excitation contraction coupling}

The excitation contraction coupling is regulated predominantly by $\left[\mathrm{Ca}^{+2}\right]$ i. Physiologically, the changes in $\left[\mathrm{Ca}^{+2}\right] \mathrm{i}$ can be considered in three phases leading to differences in contractility: basal concentrations, which are sufficient to maintain the resting tone of the myometrium, increased $\left[\mathrm{Ca}^{+2}\right] \mathrm{i}$ that occurs with contractile agonist stimulation and the restoration of $\left[\mathrm{Ca}^{+2}\right] \mathrm{i}$ to the resting state following stimulation.

The contractile machinery of the myocytes involves the interaction of myofilaments, actin and myosin. As in any other muscle, the cross bridge formation and contraction is mediated by elevated $\left[\mathrm{Ca}^{+2}\right] \mathrm{i}$ and myosin light chain phosphorylation. Irrespective of the triggering stimulus, $\left[\mathrm{Ca}^{+2}\right] \mathrm{i}$ elevation is essential for contraction (9), which may either enter from the extracellular fluid into the cell across the surface membrane through voltage-gated L-type $\mathrm{Ca}^{+2}$ channels and/or be released from intracellular stores in the sarcoplasmic reticulum (SR) (1). Both the release of $\mathrm{Ca}^{+2}$ from intracellular stores and the influx of $\mathrm{Ca}^{+2}$ from the extracellular space serve to activate the biochemical pathways which lead to actin-myosin cross-bridging and force development (2), i.e. excitation-contraction coupling.

\section{Calcium release from sarcoplasmic reticulum occurs via two mechanisms:}

Agonist or inositol triphosphate $\left(\mathrm{IP}_{3}\right)$-induced $\mathrm{Ca}^{+2}$ release (IICR) and $\mathrm{Ca}^{+2}$-induced $\mathrm{Ca}^{+2}$ release (CICR) via $\mathrm{Ca}^{+2}$ release channels (known as ryanodine receptors) on the $\mathrm{SR}$ gated by $\mathrm{Ca}^{+2}(10)$.
Agonist or $\mathrm{IP}_{3}$-induced $\mathbf{C a}^{+2}$ release: Binding of uterine agonists to a specific G-protein coupled receptor (GPCR) in the plasma membrane of uterine myocytes activates trimeric G-protein (11) and turns on a cascade of events starting with membrane phospholipase C (PLC) stimulation (12). Stimulated PLC cleaves phosphatidylinositol bisphosphate $\left(\mathrm{PIP}_{2}\right)$ to diacylglycerol (DAG) and $\mathrm{IP}_{3}$, the latter of which causes the release of $\mathrm{Ca}^{+2}$ from the SR into the cytoplasm, as indicated above (13). The $\mathrm{IP}_{3}$-mediated $\mathrm{Ca}^{+2}$ release from $\mathrm{SR}$ is the major factor adjusting resting membrane voltage (Vrest) to the value at which voltage-operated $\mathrm{Ca}^{+2}$ (VOC) channels open to trigger an action potential (AP) (14). There are two types of APs recorded in myometrial smooth muscle of various species; simple APs which have depolarisation followed by rapid repolarisation, and complex APs which have an initial depolarisation with a sustained plateau $(15,16)$. It has been suggested that the shape of $\left[\mathrm{Ca}^{+2}\right] \mathrm{i}$ transients and contractions triggered by these action potentials may be different (17).

$\mathrm{Ca}^{+2}$-induced $\mathrm{Ca}^{+2}$ release in the myometrium: Another mechanism is known as $\mathrm{Ca}^{+2}$-induced $\mathrm{Ca}^{+2}$ release, whereby the increasing $\left[\mathrm{Ca}^{+2}\right]_{\mathrm{i}}$ sensitises other $\mathrm{Ca}^{+2}$ channels to open, thus creating a feed-forward loop, although the mechanism of this phenomenon is not yet clear (14).

\section{Extracellular calcium entry}

The myometrium contains predominantly voltage-operated, large conductance L-type $\mathrm{Ca}^{+2}$ channels $(18,19)$. The presence of T-type $\mathrm{Ca}^{+2}$ channels has been recently shown, although their role has not yet been fully elucidated (20). Massive movement of $\mathrm{Ca}^{+2}$ from the extracellular space into the cytosol through these $\mathrm{Ca}^{+2}$ channels determines $\left[\mathrm{Ca}^{+2}\right]_{\mathrm{i}}$ and force generation to a much greater extent than the agonist-stimulated $\mathrm{IP}_{3}$-mediated release of $\mathrm{Ca}^{+2}(13,21)$.

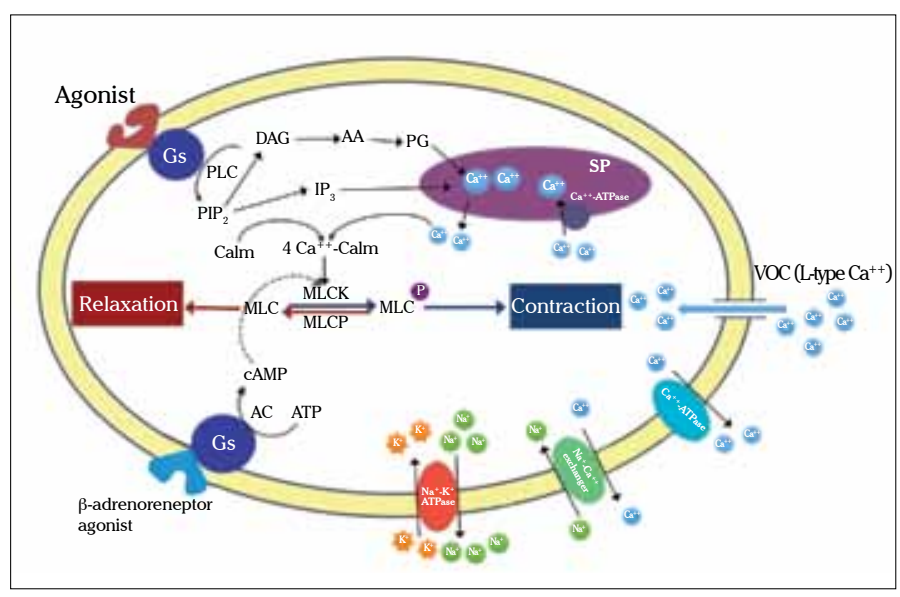

Figure 1. The schematic presentation of the physiological pathways of contraction or relaxation in uterine myocytes

(CalM: calmodulin; MLCK: myosin light chain kinase; MLCP: myosin light chain phosphatase; SR: sarcoplasmic reticulum; Gs: G-protein coupled stimulatory protein; PLC: phospholipase C; PIP2: Phosphatidyl inositol diphosphate; DAG: diacylglycerol; IP3: inositol triphosphate; AA: arachidonic acid; PG: prostaglandin; VOC: Voltage operated channels) 
Taking both mechanisms together, as supported by the experimental data from different species, it is suggested that $\mathrm{Ca}^{+2}$ release from the $\mathrm{SR}$ is transient and rapidly depleted. For this reason, even under agonist stimulation and $\mathrm{IP}_{3}$ production, oxytocin is unable to produce force in the uterus if $\mathrm{Ca}^{+2}$ entry is inhibited (21). Moreover, when the reuptake of calcium to the SR is inhibited, both $\left[\mathrm{Ca}^{+2}\right] \mathrm{i}$ transient and resulting contractions increase due to longer lasting increase in $\left[\mathrm{Ca}^{+2}\right] \mathrm{i}(21,22,23)$.

\section{Contraction}

A prominent increase in $\left[\mathrm{Ca}^{+2}\right] \mathrm{i}$ consequently activates a $\mathrm{Ca}^{+2}$-dependent cytosolic protein, calmodulin (CalM), which can bind four $\mathrm{Ca}^{+2}$ ions (24). Formation of the $\mathrm{Ca}^{+2}$-CalM complex results in the activation of a key enzyme, myosin light chain kinase (MLCK) and causes an immediate and marked increase in the phosphorylation of myosin regulatory light chain-20 (MLC20) and subsequent cross-bridge cycling (25). Phosphorylation of MLC20 by MLCK is the principal determinant of the amplitude and duration of contraction (26). MLCK contains several phosphorylation target sites for protein kinase A, protein kinase $\mathrm{C}$ (PKC) and other kinases (2). Activation of MLCK by CalM translocation of activated MLCK towards the contractile apparatus may be the rate-limiting step of contraction (14) determining the speed of contraction of the myometrium (Figure 1).

\section{Calcium sensitisation}

In some conditions, for example after stimulation with an agonist such as oxytocin or PGF2a, a given rise in $\left[\mathrm{Ca}^{+2}\right] \mathrm{i}$ will result in a stronger than expected force of contraction (27-29). This physiological phenomenon is known as " $\mathrm{Ca}^{+2}$ sensitisation" (CS) (30). Subsequent experiments have demonstrated that a pathway activated following the stimulation of GPCRs to inhibit myosin light chain phosphatase (MLCP) is the major mechanism controlling CS $(31,32)$. It can be easily predicted that this pathway involves the small GTPase rhoA and its effector, rhoA-associated kinase (ROK), since CS was shown to be diminished using a specific inhibitor of rhoA (33). The modification of the activity of MLCP (30) with phosphorylation, particularly by ROK, results in decreased activity and in turn increased force at constant $\left[\mathrm{Ca}^{+2}\right]_{i}$, i.e. an increase in $\mathrm{Ca}^{+2}$ sensitivity. On the other hand, the dephosphorylation of myosin by MLCP is usually associated with decreased force and relaxation. The ROK pathway is more important in regulating force of contraction during tonic compared to phasic contractions. Despite the large volume of literature demonstrating the relationships between agonist stimulation and $\mathrm{CS}$, the information regarding the physiological role of this mechanism in the uterus is limited (2). These mechanisms may become important therapeutic targets for the regulation of uterine activity, e.g. oxytocin may also act in part by $\mathrm{Ca}^{+2}$ sensitisation (34). However, it is clear that further study is necessary to determine the significance of CS in basal or stimulated myometrium function.

Besides the Rho-ROK pathway, PKC and activators or inhibitors of it have also been studied with regards to their potential involvement in myometrial CS both in pregnant and nonpregnant states; the findings suggest a role via the regulation of MLCP activity (35).

The pregnant myometrium is capable of larger force generation compared to the non-pregnant myometrium per unit of phosphorylated myosin light chain (36), suggesting the presence of a sensitisation system other than $\mathrm{CS}$.

\section{Relaxation of the Myometrium}

The myometrium, contracting with increasing $\left[\mathrm{Ca}^{+2}\right] \mathrm{i}$, relaxes following a series of events starting with $\mathrm{Ca}^{+2}$ dissociation from CalM, in turn inactivating MLCK, which is initiated by a decrease in $\left[\mathrm{Ca}^{+2}\right] \mathrm{i}(10,14)$. Reversal of the $\mathrm{Ca}^{+2}$-CalM-MLCK pathway follows the closure of L-type $\mathrm{Ca}^{+2}$ channels and enhanced $\mathrm{Ca}^{+2}$ efflux (Figure 1).

\section{Calcium efflux}

Calcium efflux in the myometrium is either via primary or secondary active transporters: $\mathrm{Ca}^{+2}$-Adenosine triphosphatase (ATPase) and $\mathrm{Na}^{+}-\mathrm{Ca}^{+2}$ exchanger, respectively. The affinity of $\mathrm{Na}^{+}-\mathrm{Ca}^{+2}$ exchanger for $\mathrm{Ca}^{+2}$ is low, although it is a high-capacity system. The activity of the $\mathrm{Na}^{+}-\mathrm{Ca}^{+2}$ exchanger is determined by the transcellular $\mathrm{Na}^{+}$gradient, which is determined by $\mathrm{Na}^{+}$, $\mathrm{K}^{+}$-ATPase pump activity. As a low intracellular $\mathrm{Na}^{+}$concentration is maintained by the activity of $\mathrm{Na}^{+}, \mathrm{K}^{+}$-ATPase pump, the exchanger will be activated under physiological conditions of high $\left[\mathrm{Ca}^{+2}\right]$ and $\mathrm{Ca}^{+2}$ will be removed from the cell. The primary active calcium transporter, $\mathrm{Ca}^{+2}$-ATPase, is a high-affinity system that is adjusted to keep intracellular $\mathrm{Ca}^{+2}$ low, so that resting $\mathrm{Ca}^{+2}$ levels are maintained (37). Intact uterine studies and single myometrial records show that the shares of $\mathrm{Na}^{+}-\mathrm{Ca}^{+2}$ exchanger and $\mathrm{Ca}^{+2}$-ATPase in the extrusion of increased intracellular $\mathrm{Ca}^{+2}$ are $30 \%$ and $70 \%$, respectively. The efflux ceases completely when these pathways are both blocked $(38,39)$.

The SR, acting both as a $\mathrm{Ca}^{+2}$ reservoir and a transmission pathway for $\mathrm{Ca}^{+2}$ towards two transporters, increases the extrusion rates. Although the $\mathrm{SR}$ has a considerably important role in $\mathrm{Ca}^{+2}$ signalling in other smooth muscles, its role in lowering intracellular $\left[\mathrm{Ca}^{+2}\right]$ is not very significant in the myometrium (39).

Being aware of relaxation mechanisms allows researchers and clinicians to modulate uterine contractions. First, stimulating relaxation becomes a therapeutic target to relieve undesired contractions. To achieve relaxation or decrease the force and/or frequency of contractions, $\mathrm{Ca}^{+2}$ desensitisation can be used. The phosphorylation of MLCK by several kinases reduces its activity and thus desensitises the contractile machinery $(40,41) \cdot \mathrm{Ca}^{+2}$ desensitisation, as described by Sanborn et al. (42), works via the NO-cyclic guanosine monophosphate (cGMP) signalling pathway. Briefly, cGMP-stimulated MLCP removes the phosphate from myosin, thus terminating contraction (42). Secondly, inhibition of relaxation will lead to augmented contraction, which is necessary when labour is not progressing or to achieve a strong enough contraction to prevent postpartum haemorrhage. Agents that are capable of maintaining high intracellular $\left[\mathrm{Ca}^{+2}\right]$ promote force production. For example, oxytocin, which is widely used to reinforce labour contractions, stimulates calcium entry and release from the 
$\mathrm{SR}$, and also inhibits $\mathrm{Ca}^{+2}$ efflux (43). In addition, $\mathrm{Ca}^{+2}$-sensitising agonists act mainly by inhibiting MLCP augmentation and/or elongating myometrial contractions. As noted above, ROK-associated phosphorylation of one of the MLCP subunits is the main mechanism in the inhibition of MLCP. Since this mechanism is more prominent in tonic smooth muscles, ROK inhibitors result in a little change in myometrial contractions in the uterus (44). In contrast, MLCP inhibitors acting through different protein kinase pathways have been shown to be more effective in the uterus (45).

Although the role of calcium is undeniable in myometrium relaxation, ligand-mediated relaxation is also important. A myriad of agents to prevent contraction has been tried over the years and only a small number of them have been used as tocolytic agents. The agents that are capable of uterine relaxation may intervene with the pathways which will be summarised briefly.

\section{Nitric-oxide-cyclic nucleotide pathway}

Various studies suggest a strong link between nitric oxide (NO) and cyclic GMP production (46). The mechanism of the inhibitory effect of NO/cGMP on uterine contractility, although not clear, is believed to be via decreasing $\left[\mathrm{Ca}^{+2}\right]_{\mathrm{i}}(47)$. NO alone is also shown to be involved in the activity of potassium channels and the conversion of $\mathrm{PGE}_{2}$ to $\mathrm{PGF}_{2 \mathrm{a}}$ (48).

\section{G-protein coupled receptors}

G-protein coupled receptors mediate the effect of various agonists in the myometrium. Gq-coupled receptors stimulate contraction via phospholipase $\mathrm{C}$, as stated above, whereas Gs-coupled receptors induce relaxation via the activation of adenyl cyclase (3). A very well-known example is $\beta_{2}$ adrenergic receptors coupled to Gs, which has been used for pharmacological tocolysis (49).

\section{Phosphodiesterases}

Phosphodiesterases may attenuate the activity of cyclic adenosine monophosphate (cAMP) or cGMP by contributing to their inactivation; an increased cAMP amount will decrease contractions and lead to relaxation (3). This fact resulted in the extensive use of phosphodiesterase (PDE) inhibitors as tocolytic agents in the 1980s, but this had to be abandoned due to the high incidence of side effects (50).

\section{Conclusion}

We tried to summarise the role of calcium both in contraction and relaxation of the myometrium in this review. Major advances in understanding the molecular physiology of the myometrium have been recently achieved. However, there are still key, unanswered questions, mainly concerning the role of the $\mathrm{SR}, \mathrm{CS}$ and $\mathrm{Ca}^{+2}$-activated ion channels. These issues, together with the action of agonists and antagonists on the myometrium, need further research.

Ethics Committee Approval: N/A

Informed Consent: $N / A$

\section{Peer-review: Externally peer-reviewed.}

Author contributions: Concept - B.P., S.B., M.D.; Design - B.P., S.B.; Supervision - B.P.; Literature Search - B.P., S.B., M.D.; Writing - B.P., S.B., M.D.

Conflict of Interest: No conflict of interest was declared by the authors

Financial Disclosure: The authors declared that this study received no financial support.

\section{References}

1. Wray S. Insights into the uterus. Exp Physiol 2007; 92: 621-31. [CrossRef]

2. Aguilar HN, Mitchell BF. Physiological pathways and molecular mechanisms regulating uterine contractility. Hum Reprod Update 2010; 16: 725-44. [CrossRef]

3. Bernal A.L. The regulation of uterine relaxation. Semin Cell Dev Biol 2007; 18: 340-7. [CrossRef]

4. Togashi K, Kawakami S, Kimura I, Asato R, Takakura K, Mori T, et al. Sustained uterine contractions: a cause of hypointense myometrial bulging. Radiology 1993; 187: 707-10.

5. Togashi K. Uterine contractility evaluated on cine magnetic resonance imaging. Ann N Y Acad Sci 2007; 1101: 62-71. [CrossRef]

6. Bulletti C, de Ziegler D, Polli V, Diotallevi L, Del Ferro E, Flamigni C. Uterine contractility during the menstrual cycle. Hum Reprod 2000; 15: 81-9. [CrossRef]

7. Wray S, Noble K. Sex hormones and excitation-contraction coupling in the uterus: the effects of oestrous and hormones. J Neuroendocrinol 2008; 20: 451-61. [CrossRef]

8. Hertelendy F, Zakar T. Regulation of myometrial smooth muscle functions. Curr Pharm Des 2004; 20: 2499-517. [CrossRef]

9. Wray S. Uterine contraction and physiological mechanisms of modulation. Am J Physiol 1993; 264: 1-18. [CrossRef]

10. Wray S, Kupittayanant S, Shmygol A, Smith RD, Burdyga T. The physiological basis of uterine contractility: a short review. Exp Physiol 2001; 86: 239-46. [CrossRef]

11. Phaneuf S, Europe-Finner GN, Varney M, MacKenzie IZ, Watson SP, López Bernal A. Oxytocin-stimulated phosphoinositide hydrolysis in human myometrial cells: involvement of pertussis toxinsensitive and -insensitive G-proteins. J Endocrinol 1993; 136: 497-509. [CrossRef]

12. Taylor SJ, Chae HZ, Rhee SG, Exton JH. Activation of the beta 1 isozyme of phospholipase $\mathrm{C}$ by alpha subunits of the Gq class of $\mathrm{G}$ proteins. Nature 1991; 6318: 516-8. [CrossRef]

13. Luckas MJ, Taggart MJ, Wray S. Intracellular calcium stores and agonist-induced contractions in isolated human myometrium. Am J Obstet Gynecol 1999; 181: 468-76. [CrossRef]

14. Wray S, Jones K, Kupittayanant S, Li Y, Matthew A, Monir-Bishty $\mathrm{E}$, et al. Calcium signaling and uterine contractility. J Soc Gynecol Investig 2003; 10: 252-64. [CrossRef]

15. Khan RN, Matharoo-Ball B, Arulkumaran S, Ashford ML. Potassium channels in the human myometrium. Exp Physiol 2001; 86: 255-64.

16. Bursztyn L, Eytan O, Jaffa AJ, Elad D. Mathematical model of excitation-contraction in a uterine smooth muscle cell. Am J Physiol Cell Physiol 2007; 292: 1816-29. [CrossRef]

17. Shmygol A, Noble K, Wray S. Depletion of membrane cholesterol eliminates the $\mathrm{Ca} 2+$-activated component of outward potassium current and decreases membrane capacitance in rat uterine myocytes. J Physiol 2007; 581: 445-56. [CrossRef]

18. Sperelakis N, Inoue Y, Ohya Y. Fast $\mathrm{Na}+$ channels and slow $\mathrm{Ca} 2+$ current in smooth muscle from pregnant rat uterus. Mol Cell Biochem 1992; 114: 79-89. [CrossRef] 
19. Sperelakis N, Tohse N, Ohya Y. Regulation of calcium slow channels in cardiac muscle and vascular smooth muscle cells. Adv Exp Med Biol 1992; 311: 163-87. [CrossRef]

20. Ohkubo T, Inoue Y, Kawarabayashi T, Kitamura K. Identification and electrophysiological characteristics of isoforms of T-type calcium channel $\mathrm{Ca}(\mathrm{v}) 3.2$ expressed in pregnant human uterus. Cell Physiol Biochem 2005; 4-6: 245-54. [CrossRef]

21. Kupittayanant S, Luckas MJ, Wray S. Effect of inhibiting the sarcoplasmic reticulum on spontaneous and oxytocin-induced contractions of human myometrium. BJOG 2002; 109: 289-96. [CrossRef]

22. Taggart MJ, Wray S. Contribution of sarcoplasmic reticular calcium to smooth muscle contractile activation: gestational dependence in isolated rat uterus. J Physiol 1998; 511: 133-44. [CrossRef]

23. Noble K, Wray S. The role of the sarcoplasmic reticulum in neonatal uterine smooth muscle: enhanced role compared to adult rat. J Physiol 2002; 545: 557-66. [CrossRef]

24. Johnson JD, Snyder C, Walsh M, Flynn M. Effects of myosin light chain kinase and peptides on $\mathrm{Ca} 2+$ exchange with the $\mathrm{N}$ - and C-terminal Ca2 + binding sites of calmodulin. J Biol Chem 1996; 2: 761-7. [CrossRef]

25. Shojo H, Kaneko Y. Oxytocin-induced phosphorylation of myosin light chain is mediated by extracellular calcium influx in pregnant rat myometrium. J Mol Recognit 2001; 6: 401-5. [CrossRef]

26. Butler T, Paul J, Europe-Finner N, Smith R, Chan EC. Role of serinethreonine phosphoprotein phosphatases in smooth muscle contractility. Am J Physiol Cell Physiol 2013; 304: 485-504. [CrossRef]

27. Shmygol A, Gullam J, Blanks A, Thornton S. Multiple mechanisms involved in oxytocin-induced modulation of myometrial contractility. Acta Pharmacol Sin 2006; 7: 827-32. [CrossRef]

28. Woodcock NA, Taylor CW, Thornton S. Effect of an oxytocin receptor antagonist and rho kinase inhibitor on the $[\mathrm{Ca}++] \mathrm{i}$ sensitivity of human myometrium. Am J Obstet Gynecol 2004; 1: 222-8. [CrossRef]

29. Woodcock NA, Taylor CW, Thornton S. Prostaglandin F2alpha increases the sensitivity of the contractile proteins to $\mathrm{Ca} 2+$ in human myometrium. Am J Obstet Gynecol 2006; 5: 1404-6. [CrossRef]

30. Somlyo AP, Somlyo AV. From pharmacomechanical coupling to G-proteins and myosin phosphatase. Acta Physiol Scand 1998; 4: 437-48. [CrossRef]

31. Kitazawa T, Kobayashi S, Horiuti K, Somlyo AV, Somlyo AP. Receptor-coupled permeabilized smooth muscle. Role of the phosphatidylinositol cascade, G-proteins, and modulation of the contractile response to $\mathrm{Ca} 2+$. J Biol Chem 1989; 10: 5339-42.

32. Noda M, Yasuda-Fukazawa C, Moriishi K, Kato T, Okuda T, Kurokawa K, Takuwa Y. Involvement of rho in GTP gamma S-induced enhancement of phosphorylation of $20 \mathrm{kDa}$ myosin light chain in vascular smooth muscle cells: inhibition of phosphatase activity. FEBS Lett 1995; 3: 246-50. [CrossRef]

33. Hirata K, Kikuchi A, Sasaki T, Kuroda S, Kaibuchi K, Matsuura Y, et al. Involvement of rho p21 in the GTP-enhanced calcium ion sensitivity of smooth muscle contraction. J Biol Chem 1992; 13: 8719-22.

34. McKillen K, Thornton S, Taylor CW. Oxytocin increases the $[\mathrm{Ca} 2+]$ i sensitivity of human myometrium during the falling phase of phasic contractions. Am J Physiol 1999; 276: 345-51.
35. Ozaki H, Yasuda K, Kim YS, Egawa M, Kanzaki H, Nakazawa H, et al. Possible role of the protein kinase C/CPI-17 pathway in the augmented contraction of human myometrium after gestation. $\mathrm{Br}$ J Pharmacol 2003; 7: 1303-12. [CrossRef]

36. Word RA, Stull JT, Casey ML, Kamm KE. Contractile elements and myosin light chain phosphorylation in myometrial tissue from nonpregnant and pregnant women. J Clin Invest 1993; 1: 29-37. [CrossRef]

37. Matthew A, Shmygol A, Wray S. Ca2+ entry, efflux and release in smooth muscle. Biol Res 2004; 37: 617-24. [CrossRef]

38. Shmigol AV, Eisner DA, Wray S. Properties of voltage-activated $[\mathrm{Ca} 2+] \mathrm{i}$ transients in single smooth muscle cells isolated from pregnant rat uterus. J Physiol 1998; 511: 803-11. [CrossRef]

39. Shmigol AV, Eisner DA, Wray S. The role of the sarcoplasmic reticulum as a $\mathrm{Ca} 2+$ sink in rat uterine smooth muscle cells. J Physiol 1999; 520: 153-63. [CrossRef]

40. Horowitz A, Menice CB, Laporte R, Morgan KG. Mechanisms of smooth muscle contraction. Physiol Rev 1996; 76: 967-1003.

41. Weber LP, Van Lierop JE, Walsh MP. Ca2+-independent phosphorylation of myosin in rat caudal artery and chicken gizzard myofilaments. J Physiol 1999; 516: 805-24. [CrossRef]

42. Sanborn BM, Ku CY, Shlykov S, Babich L. Molecular signaling through G-protein-coupled receptors and the control of intracellular calcium in myometrium. J Soc Gynecol Investig 2005; 12: 479-87. [CrossRef]

43. Soloff MS, Sweet P. Oxytocin inhibition of (Ca2+ Mg2+)-ATPase activity in rat myometrial plasma membranes. J Biol Chem 1982; 257: 10687-93.

44. Kupittayanant S, Burdyga T, Wray S. The effects of inhibiting Rhoassociated kinase with Y-27632 on force and intracellular calcium in human myometrium. Pflugers Arch 2001; 443: 112-4. [CrossRef]

45. Sakamoto Y, Harada T, Horie S, Iba Y, Taniguchi F, Yoshida S, et al. Tumor necrosis factor-alpha-induced interleukin-8 (IL-8) expression in endometriotic stromal cells, probably through nuclear factor-kappa B activation: gonadotropin-releasing hormone agonist treatment reduced IL-8 expression. J Clin Endocrinol Metab 2003; 88: 730-5. [CrossRef]

46. Buhimschi I, Yallampalli C, Dong YL, Garfield RE. Involvement of a nitric oxide-cyclic guanosine monophosphate pathway in control of human uterine contractility during pregnancy. Am J Obstet Gynecol 1995; 172: 1577-84. [CrossRef]

47. Word RA, Casey ML, Kamm KE, Stull JT. Effects of cGMP on [Ca2+] i, myosin light chain phosphorylation, and contraction in human myometrium. Am J Physiol 1991; 260: 861-7.

48. Farina MG, Billi S, Sordelli MS, Ribeiro ML, Di Girolamo G, Lombardi $\mathrm{E}$, et al. Nitric oxide (NO) inhibits prostaglandin E2 9-ketoreductase (9-KPR) activity in human fetal membranes. Prostaglandins Other Lipid Mediat 2006; 79: 260-70. [CrossRef]

49. Anotayanonth S, Subhedar NV, Garner P, Neilson JP, Harigopal S. Betamimetics for inhibiting preterm labour. Cochrane Database Syst Rev 2004; 4: CD004352.

50. Méhats C, Schmitz T, Breuiller-Fouché M, Leroy MJ, Cabrol D. Should phosphodiesterase 5 selective inhibitors be used for uterine relaxation? Am J Obstet Gynecol 2006; 195: 184-5. [CrossRef] 